Article

\title{
"Improving Our Way of Life Is Largely in Our Own Hands": Inclusion according to the Romani Newspaper of Interwar Yugoslavia
}

\author{
Sofiya Zahova \\ School of History, University of St Andrews, St Andrews, KY16 9AR, UK; E-Mail: sdz@st-andrews.ac.uk
}

Submitted: 15 January 2020 | Accepted: 16 March 2020 | Published: 4 June 2020

\begin{abstract}
The only Romani newspaper of interwar Yugoslavia, Romano lil/Ciganske novine (the latter meaning 'Gypsy newspaper' in Serbian), was published in Belgrade in 1935 comprising only three monthly issues. The most prominent Yugoslav Romani activist of the time, Svetozar Simić, was the editor of the newspaper, giving tribute to his visions of what Roma should do for the prosperity of their own community. In terms of content, the newspaper articles seem to be strategically thought-out with the aim of creating a narrative about the Roma, as people united by common culture and historical memory, equal to the other people of the Yugoslav Kingdom, who needed to be included in all processes of the social and public sphere. This article looks into the essence of some messages that the newspaper conveys regarding Roma's social inclusion, such as (1) education and professional training as a key for a better future, (2) the need for Roma to be more engaged and to self-organise as a community and (3) the fight against majority misconceptions about the Gypsies. The article presents and analyses these three elements of Svetozar Simić's visions for Romani social inclusion as presented in his editorial pieces. The analysis also pays attention to the resemblances between some of the main messages of the Romani activism in the interwar period and the activism for Roma inclusion in later periods, including parallels during the time of Yugoslav Socialism and the period of democratic transition up until today.
\end{abstract}

\section{Keywords}

education; inclusion; interwar Yugoslavia; minorities; newspaper; Romani activism; Romani journalism; Romano lil/ Ciganske novine; Serbian Gypsies; Svetozar Simić

\section{Issue}

This article is part of the issue "Gypsy Policy and Roma Activism: From the Interwar Period to Current Policies and Challenges" edited by Elena Marushiakova (University of St Andrews, UK) and Vesselin Popov (University of St Andrews, UK).

(C) 2020 by the author; licensee Cogitatio (Lisbon, Portugal). This article is licensed under a Creative Commons Attribution 4.0 International License (CC BY).

\section{Introduction: The Newspaper and Its Editor}

Similar to most countries in Central, Eastern and Southeastern Europe, in interwar Yugoslavia Romani civil activism has developed. In Belgrade there were established few Roma-led organisations and several other initiatives took place regionally. Romano lil/Ciganske novine (the latter meaning 'Gypsy newspaper' in Serbian), initiated and edited by Svetozar Simić, was the first and only Roma-led journalistic endeavour in interwar Yugoslavia. According to the editor: "Our newspaper has been set up in order to write about Gypsies, but understandably for Gypsies" (Simić, 1935a, p. 1). The monthly four-page edition had only three issues released between March and May 1935 and, allegedly had a print run of 1,000 copies for the first two issues and 5,000 copies for the third one (Jopson, 1936, p. 87).

Svetozar Simić was the brain behind Romano lil/Ciganske novine and the editor, manager and main author of the newspaper. Born in 1913 to a Romani family, in a village near Arandjelovac in Central Serbia, he moved to Belgrade after graduation from high school. He continued his studies in the Yugoslav capital, becoming a Law student in 1935 (Acković, 2014, p. 357). In the 1930s, together with Aleksandar Petrović, an employee at the Institute for Hygiene who was researching Gypsies in Serbia and publishing in Serbian and abroad, Simić co-authored three studies on Gypsies (Petrović \& Simić, 1934a, 1934b, 1934c). Throughout his lifetime, Simić also worked on Romani grammar and vocabulary, 
writing down customs and legends, all unpublished thus far. He was one of the main young figures in the civil activities among the Belgrade Gypsies, and practically the only activist of Romani background who authored and published materials in the public field during the interwar period. Simić was the founder and president of the Educational Club of Yugoslav Gypsy Youth that existed shortly before the start of the Second World War (see Section 2). After 1946 Simić focused mainly on his personal career but continued being active in the field of Romani issues. In the late 1960s he addressed a letter to the authorities proposing inclusion of the term 'Rom' in the National Statistical Institute categories with regards to the forthcoming Yugoslav-wide census of 1971. Thus, he might well have been the first Romani activist to raise the issue publicly in the late 1960s (similar demands were made by Slobodan Berberski, a Romani activist and member of the Communist Party Leadership in Belgrade), or at least his efforts were in the same direction as the Romani activism of the time in Socialist Yugoslavia. Simić also continued writing and maintained his contacts within the network of Romani activists and researchers of Romani culture throughout his life. For instance, he was corresponding with Rade Uhlik, a linguist and one of the few researchers interested in studying the Roma in Yugoslavia throughout the 20th century. In the interwar period, Uhlik actively collected oral traditions and studied the Romani Bosnian dialects, published a Romani language collection of traditional folklore songs (Uhlik, 1937), and translated into Romani The Gospel of Saint Luke (Uhlik, 1938).

According to information published in a review of Romano lil/Ciganske novine in the Journal of the Gypsy Lore Society, Aleksandar Petrović is reported as the person who founded and tried to financially maintain the newspaper, despite all obstacles (Jopson, 1936). Petrović was indeed one of the main contributors to the newspaper and, despite the fact that he is not explicitly mentioned in the newspaper administrative records, he might well have been a collaborator in Simić's endeavours, as materials he wrote form a substantial part of the small newspaper. Nothing, however, points to the fact that Aleksandar Petrović was the one who started or tried to maintain the endeavour. In fact, all preserved documents from the bookkeeping and archive of the newspaper-manuscripts, financial records and printed copies-point to the fact that Svetozar Simic was the main figure behind its publishing. Furthermore, a comprehensive article in the genre of a portrait interview with Simić was published in one of the most influential daily newspapers in Yugoslavia, Vreme, which elaborates on the short newspaper's history and records Simić's setting up an editorial office in his father's house in one of the Gypsy neighbourhoods of Belgade (Mitrović, 1936). We may speculate why Petrović had misrepresented himself, and had been further misrepresented in the Journal of the Gypsy Lore Society publication, as the editor and main agent behind Romano lil/Ciganske novine. In a let- ter dated 12 May 1935 to Scott Macfie, then an editor of Journal of the Gypsy Lore Society, Petrović sent two copies of the newspaper. In the accompanying letter he wrote:

I edit it and publish it together with a Gypsy student. But none of the Gypsies buy it. I had the idea to assemble as many as possible literate Gypsies around it, but it seems it won't be a success. I keep a diary of the history of the paper. All my experience in connection with it will be a very good contribution to the study of the Gypsy psychology. (Petrović, 1935)

What strikes one here is that the actual-and wellknown to the Belgrade public-editor of the newspaper, Svetozar Simić, is reduced to an anonymous "Gypsy student." Petrović, as author of a series of contributions on Serbian Gypsies in the Journal of the Gypsy Lore Society (Petrović, 1937; see also third series of the journal, volumes 14 through 19) and main correspondent of the leadership of the Gypsy Lore Society in the interwar period, was an authority whose claims were accepted without doubt or call for verification. Also, it seems that Petrović viewed the whole processes as a scientific experiment to contribute to the study of Gypsy psychology which was covered extensively in his publications, quite in unison with the racial discourse of the time. I agree with the opinion of Acković, in a personal communication dated 7 December 2018, that this is a clear case of purposeful falsification. This pattern is linked to the historically affirmed practice of marginalization and underestimation of Roma, who are not to be viewed as active agents in their own history and culture and always needed to be led by non-Roma.

All three issues of Romano li//Ciganske novine comprised four pages and followed a similar newspaper structure: an editorial, frontpage article or introductory note by Svetozar Simić (in the second issue this piece is written by Aleksandar Petrović), a large second page devoted to Romani history and culture, shorter pieces reflecting on contemporary issues (e.g., the death of King Alexander I Karadjordjević, health issues, etc.) and the final part with Romani folklore-short tales, recorded texts of songs in the original Romani and translated by Simić and a feuilleton by Simić. The articles were mostly written by latter, with several large pieces by Aleksandar Petrović and M. Milić, an educated Rom who was also co-founder of the newspaper (Simić, 1935b, p. 1).

In his first editorial, Simić states that the newspaper is for Roma and about Roma, and thus directed to both Romani and non-Romani audiences, positioning itself as a counterpoint to the image of the Roma spread in other mainstream media:

A newspaper such as ours could be edited in two ways: It could be written about Gypsies and in it could be written for Gypsies. If we were to write only about Gypsies, we would have to take a bit into account the 
various tastes of our gadjo (non-Gypsy) readership. Without a variety of 'stars,' e.g., black and Gypsy, and their respective pictures, our newspaper would hardly survive. No matter how good-looking, attractive and adorable our black beauties are, we still do not mean to write about them. Our newspaper was launched in order to write about the Gypsies, but of course, for the Gypsies. (Simić, 1935b, p. 1; italics in the original)

Due to financial unsustainability and lack of funds, the newspaper had only three issues. The memory about it, however, was kept among Belgrade Romani activists as an inspiring example of both activism and journalism, and the need to revive it was raised in the decades to follow (Berberski, 1969, p. 51). As a matter of fact, Simić was not directly involved in the formal networks of Romani activism after the interwar period, although he continued to follow Romani movement developments and worked on a collection of essays reflecting on his juridical practice, including as lawyer of Romani people.

In terms of content, the newspaper articles seem to be strategically thought-out, with the aim of creating a narrative of the Gypsies as people united by common culture and historical memory, thus equal to the other people of the Yugoslav Kingdom, who needed to be included in all processes of the social and public sphere. Particular attention is due to Simićs editorials, especially those of the first and third issue. These pieces can be called visionary programmes, shedding light on both problems and their solutions for a desired future of the Roma.

The current article looks into the essence of several of the most important messages that the Romano lil/Ciganske novine conveys on Roma's social inclusion, outlining three main aspects: (1) education and professional training as a key for a better future, (2) the need for Roma to be more engaged and self-organise as a community and (3) the fight against majority misconceptions about the Gypsies. The article presents and analyses the way in which Simić's editorials discuss these points, as well as how they outline concrete steps for Romani social inclusion. The article also elaborates on the resemblance between some of the messages of the Romani activism in the interwar period and of the activism for Roma inclusion in later periods, including parallels with the time of Yugoslav Socialism and the period of democratic transition up until the present.

\section{The Yugoslav Context: General Developments and Romani Activism}

There were dynamic processes in terms of ethno-cultural and political development in interwar Yugoslavia. The review of the Yugoslav archives of the time and the already published scholarship (Banac, 1988; Dimić, 1996) show that the state efforts in the fields of culture, civil organisation and religious activities, both centrally and locally, were focused on strengthening a Yugoslav identity, especially among the youth, counteracting centrifu- gal activities labelled as nationalist and anti-Yugoslav, and activities related to ethnic communities with nation states outside of Yugoslav borders (German, Romanian, Czechoslovakian, etc.). There were two population censuses in the interwar period, 1921 and 1931, but none of them collected data that could be directly related to Roma. The main national categories were related to the three entities in the Kingdom-Serbs, Croats, Slovenes. There are researchers who quote various numbers of the Yugoslav Roma population of the time, based mainly on ethnographic data and observations. According to Tatomir Vukanović (1983, p. 121) the number of Gypsies in the Serbian territories of the Kingdom of Yugoslavia in 1921 was 34,919 . Rajko Đurić $(1987$, p. 67) estimates that Roma, in interwar Yugoslavia, numbered 250,000.

The Romani cultural, political and civil initiatives were not an object of interest to the state and there were no political measurements in these fields that referred to the Roma. This, however, does not mean that there were no such initiatives. As Acković (2000) has argued, there were such activities and they were all based on grass-root initiatives and self-organising efforts of Roma, formal (in accordance with the general legislative regulations) and informal. There were accomplishments led by Roma, e.g., a couple of organisations and the newspaper enterprise that is the main study object of this article. Among them were the First Serbian-Gypsy Association for mutual support in sickness and death (Prva Srpsko-Ciganska zadruga za uzajmno pomaganje u bolesti i smrti), active in the 1920s and 1930s, that most probably was based on an earlier form of community organisation, whose goals were to provide its members with help and support on various occasions. The second known organisation is the so-called Club of the Belgrade Serbian Gypsies (Klub beogradskih srpskih Cigana), and information about its activities reported in media points to the fact that the Club claimed rights for political representation and participation in the decision-making bodies at the local and national level. More is known about the third one, the Association of Belgrade Gypsies Worshippers of "Bibija" (Udruženje beogradskih Cigana svečara "Bibije"), established in 1935. According to this association's statute, its goals included raising the cultural level of all its members by establishing new cultural and social institutions, accepting gifted kids and young people with the aim of education and study of crafts (Marushiakova \& Popov, in press).

The fourth organisation, the Educational Club of the Yugoslav Gypsy Youth (Prosvetni klub jugoslovenske ciganske omladine), active in the late 1930s, was presided by Svetozar Simić (Nikolić, 1939, p. 10). The club was modelled similarly to other Yugoslav-wide youth organisations, so its primary goal was gathering Romani youth for further education and enlightenment. There were several types of activities characteristic of youth organisations (Žutić, 1991) that were developing in Yugoslavia as part of the Kingdom's politics of identitysport activities, cultural activities, including amateur arts, 
and the so-called analphabetic streams that were supposed to fight illiteracy among large groups by basic literacy lessons and public lectures on topics such as health, hygiene, history.

It should be noted however, that these organisations were not the only examples of Romani community initiatives of civil nature in interwar Yugoslavia. There also were Romani initiatives active in the cultural, social or religious life at the local level. Such examples are, the initiative for the building of so-called 'Gypsy Church' after the First World War in Privlaci (today in Eastern Croatia) with donations from the Rom Čedomir Nikolić, where in 1938, in front of Romani audience from the Vukovar-Srijem region, the newly translated Gospel of Luke (Uhlik, 1938) was read (Acković, 2014, pp. 205-208). In Niš, Southern Serbia, in 1928, the Gypsy Singing Society Sloga was established, and in 1932 the football club Gajret, that according to local community memory was entirely comprised of Roma, although it was not officially stated that it had an ethnic character, was founded (Jašić, 2001, p. 25).

Similar processes related to Romani activism and community self-mobilisation took place in the social and political context of all nation states in the region of Southeastern Europe (Achim, 2004, pp. 153-159; Marushiakova \& Popov, 2005, pp. 445-447). Although the developments in Yugoslavia seem to be more limited and informal in comparison with neighbouring countries like Romania and Bulgaria, there was one very important common feature. Similar to the other countries in the region, the roots of Yugoslav Romani activism were not in top-down but in grass-root initiatives, driven by Roma activists and organisations, aiming to mobilise the community using civic engagement mechanisms characteristic of the respective period and nation-state. In the Yugoslavian context, these organisations often continued, intertwined with and based on traditional practices of community gatherings that were appropriated into new forms of civil organisations to unite and claim common interest of the Roma, and were thus comparable to other Yugoslav organisations of the same period. Most of them were led by Belgrade Roma and took place in Belgrade. It is of course natural that Belgrade Roma, being based in the Kingdom's capital, i.e., and at the forefront of the socio-political arena where policies were coined, positioned themselves as elite that should represent all Gypsies in the state and come up with leadership ideas and strategies for the development of the whole community within Yugoslavia. The presence of these ideas in the public space and on the level of formal and informal organisations' programming showed that leadership groups of Yugoslav citizens of Romani background were actively working for the advancement and social inclusion of the Roma as people within the Yugoslav national or/and local context. The Yugoslav multi-ethnic and multi-confessional context proved to be a stimulating environment for the development of the Romani social and political organisations. The activism of Svetozar Simić should be interpreted in light of these developments.

\section{Education}

The analysis of the preserved materials about the abovementioned organisations' activities, especially the ones of the 1930s, shows clearly the emphasis on work for both the education of the Romani youth and Romani community's self-mobilisation. The overall strategy was cultural and educational development of all generations of Roma. A great deal of the first editorial article by Svetozar Simić was devoted exactly to his visions about literacy and education, in a broad sense, of the community at large:

Life is a desperate battle, the winner is the one who is stronger and better skilled. In order for a person to be able to earn a slice of bread for himself and his children, he should fulfil at least two conditions: to be literate and to have a permanent occupation in his hands....And we think that the only remedy for this evil and shame is that every one of our children is attending a school, and after the end of the school [the child] starts immediately to learn some craft or some skill. A man who starts working since childhood, gets used to it, and can never sit without work afterwards....That's why we have launched our newspaper. With it we want to open our brothers' eyes and show them that it is our first and foremost task to send our children to school, in order to become literate, and to let them learn some craft or skill right after graduation. Whoever could afford and wishes more, let them give the children to learn trade or to attend schools. And let our children learn there, with good masters and teachers, how to fairly earn a piece of bread. (Simić, 1935a, p. 1)

Reading the quoted parts of Simić's first editorial as a visionary programme, several points are worth elaborating upon. In the first place, he prioritised education as the only path to success in profession and in life. Yugoslavia's population, during the interwar period, had a great percentage of illiteracy. Increased literacy and access to education was a priority of the Kingdom during this time. In addition, a common Yugoslav identity was to be created, namely through education. Although Roma were not specifically targeted or mentioned in these policies, it is clear that the vision of Simić as a leader, and as a rare example of an educated Rom himself, was to include Romani community's development in the general tendencies of the time. He obviously planned and hoped for the young Romani generations to be enrolled in school as their peers. The stress on professional training in crafts and trades was also not coincidental: The modernisation of the Yugoslav state after the First World War included transformations in which the traditional crafts were to be upgraded into more modern forms, in order to be included in the general economy of the dynamically developed urban and manufacturing environment, particularly in Belgrade. The proposed plan for professional 
training of the Roma, i.e., in schools and other institutions, was also in unison with the idea that Roma had to catch up with all processes of their contemporaries.

Another aspect that is only hinted at here was present on the pages of Romano lil/Ciganske novine, and was later implemented into activities by Simić as President of the Educational Club of the Yugoslav Gypsy Youth in the late 1930s. This was the need to educate the illiterate older generation through activities in socalled analphabetic stream, that was largely developing in Yugoslavia at the time. The aim of all these activities, was cultural elevation (Nikolić, 1939) and the development of lifelong working habits. If we interpret these strategies in the phrases of the contemporary Romani activism, Simić was pleading for inclusion in the educational system in order to achieve inclusion in the labour market and society. Note that these requests were not directed towards institutions, but towards the Roma themselves, and particularly towards the families responsible for Romani kids.

With the renaming of the Kingdom of Serbs, Croats and Slovenes into the Kingdom of Yugoslavia in 1929, certain policies in the field of education and culture were designed in order to reinforce a Yugoslav identity as one of the responses to centrifugal and nationalistic tendencies of the Kingdom's territories (Dimić, 1996; Gligorijević, 1986). The period of the 1930s in Yugoslavia was related to a general discourse and policies for building a Kingdom-wide network of youth clubs related to various sports, cultural and educational activities, and was connected to a general strategy of building a Yugoslav identity among the new generations (Žutić, 1991). Elevation of the general educational status was one of the strategies presented in Yugoslav public discourse, and also in the activities of various nation-wide clubs of youth and community organisations. The special stress on educating the youth and the future generations in the programme articles of Simić shows that the Belgrade community activist was shaping policies in the spirit of the Yugoslav time and context, and at the same time planning an educated Roma leadership for the future.

As a matter of fact, the essence of this discourse has not significantly changed for almost a century, although there have been shifts in the aim and justification of the need for education. Looking at the time of Socialist Yugoslavia, Roma activists have stressed the importance of education of Roma so that they had better labour opportunities, as shown from the speeches delivered by Slobodan Berberski and many other Roma at the founding assembly of the Rom Association (Društvo Rom) in Belgrade in 1969 (Berberski, 1969, pp. 49-50). Roma education has been one of the priority areas in the discourse of all post-socialist transition societies, including those of former Yugoslavia. The largest share of the budget of the Serbian Roma National Council, for instance, has been devoted to projects in the field of education. There are, however, several shifts in the focus of Romani educational policies in the discourse of Romani activism and civil sector in the post-socialist period. The stress during the interwar period was, in the spirit of the time, for mass basic education of large numbers of illiterate citizens, on obtaining basic education in formal educational institutions or informal courses and building up working habits of the newly educated. The focus during the period of Socialism was to secure basic education and inclusion in the labour market. Finally, the stress in the postSocialism period was on educational competences that went beyond basic education and were implemented through investments in programmes securing quality education at all levels, stressing the importance of preparation and enrolment of Romani students in universities. The strategy for increasing the number of such students and Roma with university education was articulated in the policy documents of the Roma Education Fund, an international organisation founded in 2005, with regards to general developments (Roma Education Fund, 2010a, p. 19), as well as to certain countries (Roma Education Fund, 2010b, pp. 39, 93).

\section{Civil Participation and Community Self-Mobilisation}

What is interesting to point out is the fact that these visions for a desired development for Roma in the field of education and culture, to subsequently lead to their social integration, were not related to demands from the state, political or government measures. They were connected to demands towards the Roma themselves or as Simić writes in his third (and last) editorial:

An interesting attempt was made in that direction by another member of our editorial team, Mr. Milić. He collected in his backyard a group of 15 to 20 men and women of different ages and read to them the newspaper from the beginning to the end. After every article he read, he explained to them in his own words in Romane (in Gypsy language) what he had read to them. Then started the questions that developed into entire discussions. If we could find more people like Mr. Milić, we could get an even greater interest in our newspaper among our people. We should not forget that our newspaper has to fulfil a cultural first-order mission. From the interest in certain poems and stories printed on a language spoken by them, our people are turning to more serious things, to our life in general. The question of improving our way of life is largely in our own hands. A little more economy in the house, higher order and cleanliness: a little less visit to the kafana, less card-playing, less drunkenness; and most of all, more literacy, paying more attention to our children and their preparation for the future lives, we will live better and better. The future will show, if we would be able to convince our brothers and sisters, how important it is for each of our children to complete elementary school and learn some crafts. (Simić, 1935 b, p. 1; italics in the original) 
This could be seen as meaning that the state had already secured the Roma as citizens with access to education and professional realisation, as well as with means for cultural elevation. According to this narrative, it is thus a question of Romani's own agency, initiative and self-organisation to achieve their better future through using the already existing mechanism in their environment. In the lines above we also see a vision and direction towards a common identity building among the Roma under the leadership of more educated and literature individuals, a well-known pattern for the ethnonational states in Eastern and Central Europe region, developed in 19th and beginning of the 20th century, after the Herderian model for national emancipation: namely, through the collection and publishing of materials representing the folkloristic and linguistic heritage of the respective peoples on behalf of the educated elite that works for the 'folk spirit,' the large mass of community will identify with the published material (in this case in the newspaper) and will recognise its leadership role.

Drawing a vision for Roma and their opportunities for a better future, and in relation to the need for a Romani agency in achieving prosperity for the Roma as a collective, some parts of Simić's articles also engage with a critique from within the community and disapproving some actions, views and habits among the Roma that were seen as preventing them-to use the words of the newspaper-from "elevation to another cultural level" (Simić, 1935b, p. 1). There are two common themes in this respect that appear in more than one issue of the newspaper. The main critique, observed in the editorial articles by Simić and interrelated to the already discussed topic of Romani education, is towards the community itself for not paying enough attention to the schooling and professional skills of their children. Another critique is about the lack of interest in Romani civic activism among the educated and successful Roma towards whom Simić is particularly critical, as they are the ones who are supposed to take an active engagement concerning their own community: "And then why, sweet brothers, our richer brothers are ashamed of their own brothers, their name, their blood?" (Simić, 1935a, p. 1). In "Our intelligentsia and aristocracy," signed by Milić, but clearly influenced by Simić editorial style, we read:

Among us, however, they are lords. But the only problem is that they are ashamed, even though they were also born to a Gypsy woman and breastfed with her milk. But they can do a lot for us. Can't they be more engaged with this, until literacy spreads among our people? Can't they create one association that would assist us in a case of sickness and death. They can help us create reading rooms and courses for our illiterate adults. They could help us a lot so that every child of ours learns a craft and profession and honestly earns his bread.
Unfortunately, they do not do anything of this sort. Just the opposite, those who call themselves 'Gypsy intelligentsia' and 'Gypsy aristocracy' doctors and other state servants are openly against our newspaper. They spread the word among our illiterate brothers, especially among women, that our newspaper only disgraces the Gypsies, that the owner of our newspaper is against Gypsies, and that the Gypsies should not read and support the newspaper. (Milić, 1935, p. 2)

This critique from within, on the pages of the third issue of Romano lil/Ciganske novine, actually accuses Roma of a lack of civil engagement and activities for the benefit of the Romani community as a collective. The main critique addresses primarily those who are literate and educated, as they are the elite, the ones who are supposed to engage in an active position towards their own community, to establish leadership roles in solidarity and prosperity, and to lead the community mobilisation in various fields. The author portrays them, however, as either passive and uninterested toward topics discussed in the Romano lil/Ciganske novine, or as people with negative opinions towards the Gypsy newspaper mainly because of the criticism addressed to the Romani community.

The key role of the Romani leadership for community prosperity and self-organisation continued to be an essential element in Romani movement discourse, bearing the sign of each period. The socialist Yugoslavia Rom Association leadership spoke about producing cadres "who can shorten the way for affirmation and constitution of a Roma nationality" (Berberski, 1969, p. 51) and help Roma become equal Yugoslav citizens. Berberski, the most prominent Romani activist leader of the Yugoslav time in the 1970s, was directly pleading for Roma social inclusion through work of Roma but also for work by the social institutions for Romani inclusion (Berberski, 1973, p. 4). In the transition period, there has been a plurality of leadership forms, for instance Romani non-governmental organisations, working on Roma issues by advocacy and equal rights' claims, political participation of Roma representatives in national and local level of government. While the critique towards factors that are external to the community was predominant, strategical papers of Romani activists still recognised that certain questions had to be raised within the community itself in order to tackle existing problems (Gheorghe, 2013). Another point presented in Romano lil/Ciganske novine articles-that the successful individuals are not engaged in community work and are afraid to publicly come out as Roma-has also been present in private and public statements by Roma activists (Djurić, 2009).

\section{Fight against Misconceptions about Roma}

The fact that the main issues discussed by the newspaper articles were related to a critique towards the Romani community internally, does not mean that the image of the non-Roma was completely absent or that a critique 
towards the majority community was not present. The most frequently used term to name the non-Roma, in the Serbian language articles of the Romano lil/Ciganske novine, is the Romani word, namely gadje, provided in its Romani original followed by a Serbian translation. In this way the newspaper legitimised its positioning as a tribute that represented the Romani point of view and also introduced the Romani concept to the non-Romani audiences. Rarely in use was the word non-Gypsies (necigani). Serbs, being the non-Roma population with which the Roma from Belgrade and in the region were in contact, were also present and named in tales and oral folklore narratives, published in the newspaper, but also when referring to the non-Roma audience in general.

Simić also engaged in a critique of the macro-society and mainly its mistaken beliefs about the Roma prevalent in public discourse. He addressed in his articles two of the most common and widespread misconceptions about the Gypsies (present in all historical periods and geographical areas), namely those concerning Gypsy criminality and Gypsy begging. In his first editorial Simić challenges the wrong perception of begging as a Gypsy cultural practice by providing an explanation related to the social circumstances in which every person, regardless of ethnicity, could find himself in. Indirectly, he hints towards the fact that if the social infrastructure of a state cannot provide for its citizens finding themselves in a difficult situation, then begging is just a survival strategy. Furthermore, Simić criticised begging as a practice misused as an occupation replacing proper forms of work. He ended with a clear message that begging as an occupation was unacceptable the collective:

But if we are not blamed for what the newspapers write, we must think carefully about another misfortune that bursts upon our neck. Many gadje (nonGypsy) think that a Gypsy and a beggar are the same thing. However, this is not the case. There are two types of begging. The first is: When a man loses his job, he is hungry, his children are hungry. If the state or the municipality does not help him as a citizen of this country, then only two exits are left to such a man if he does not want to die of starvation: either ask for a piece of bread or steal it. Asking for a piece of bread is forbidden neither by religion nor by law. Only the one who steals from others is punished. The second one is the kind of begging when a person, instead of working, goes around and in various ways, lures money from honest and pious people for bread. We, all the Gypsies, whatever number we are, are against such kind of begging. We are fighting and will be fighting against it. (Simić, 1935a, p. 1; italics in the original)

Additionally, from the position of a Romani run newspaper, addressing a wide reading audience, Simić in the first place discusses and challenges narratives that were characteristic for the mainstream media reporting criminals and criminal activities, not by naming the perpetrator, but by pointing out on the first place the fact that this is a Gypsy, suggesting equalisation of criminality and being Gypsy in general. Indeed, a look into the media of the time, shows that most of the newspaper materials are related to reporting illegal and criminal activities by Gypsies. Simić, a law student at that time, also disputes the legal absurdity of attributing collective guilt to an individual's criminal acts:

All Gypsies are not and cannot be guilty if one of them breaks the law, and the newspaper instead of saying: this and that, by name and surname, did this and that, they report in large bulky letters: Gypsies have stolen...Gypsies have cheated...Gypsies have killed...Gypsies have been mutilated...have blinded...Gypsies...Gypsies...Gypsies. As if there is not a single criminal act in the world in which a Gypsy guy has not been involved. In human history, there has not yet been such a case in which the act that an individual belonging to a given people may have done something but it is attributed to all the people. And all Gypsies could never answer for the deeds and idleness of individual Gypsies. (Simić, 1935a, p. 1)

As a matter of fact, both non-Roma narratives (about equalisation of Gypsy with criminality and with beggary) challenged by Simić are still present in the public discourse and continue to be addressed by Romani activists in both (post)Yugoslav space and across the world, often interpreted in the framework of anti-discrimination and anti-Gypsyism. Still today, many Roma activists from Yugoslav countries in their public interviews insist on the fight against prejudices and their consequences (Djurić, 2009).

Also, similarly to Simić's statement against any begging practice among Roma that substitutes for a job, there are activists, such as Nicolae Gheorghe who state that Romani intellectuals and activists have to tackle begging as a practice as leaders of their community (Gheorghe, 2013). At the same time, little has changed regarding the majority of society's ideas about begging. Looking at this discourse globally, there are cases of localities where, despite the existing ban on begging, Romani begging was tolerated because of the dominating discourse of this as a Roma cultural practice or occupation (Marushiakova, \& Popov, 2016, p. 238). To the famous case of Italy, where despite the clear statements of Roma activists that begging is not part of Roma culture or traditions, the Italian Supreme Court in 2008 declared begging a traditional way of life deeply rooted in the Romani culture, a recent one from Sweden can be added. Again, Romani activists raise voices and point out that begging is not a Romani cultural practice, and demand that the Swedish state should create better living and working conditions for the Romanian Roma who currently beg and live on the streets. Since 2016 there have been constant attempts to manage and institutionalise locally or nationally by issuing permits to beggars or by introduc- 
ing a fee on begging, considering it as a street occupation practice ("Swedish town becomes first in country to introduce licence fees for beggars," 2019). As a reaction to this, Hans Caldaras, a Swedish Romani artist and activist, publicly spoke against such regulations, pointing out that, if setting up a fee, the authorities should be able to justify such actions against the poorest Roma coming to Sweden.

Similar to Simić's rhetoric, Caldaras points to the fact that Romani people who beg have no other options for survival and are at the bottom of existence. In the Swedish Romani activists' discourse, however, in contrast with writings of Simić and Gheorghe, there is no critique of begging and other practices, such as crime and early marriages, that according to activists as Nicolae Gheorghe, have to be tackled by the Romani movement in order to mobilise and change their own community.

\section{Conclusion}

The interwar period saw the birth of Romani civil activism and the emergence of the first Roma-initiated publications in the public space in most of the countries of Central, Eastern and South Eastern Europe. The Kingdom of Serbs, Croats and Slovenes (Kingdom of Yugoslavia since 1929) was not an exception. The Yugoslavian capital was the place where most of these activities took place-the few Romani organisations from that time established and developed activities there, the only Roma-led newspaper Romano lil/Ciganske novine published there and the first Yugoslav-wide organisation (Educational Club of the Yugoslav Gypsy Youth) set up there for only a couple of months before the Second World War. The most prominent Yugoslav Romani activist of the time, Svetozar Simić, started Romano lil/Ciganske novine, giving tribute to his own visions about the need for social inclusion of the Roma and the paths to achieve it.

The three major areas for action outlined in Romano lil/Ciganske novine articles and discussed hereeducation for ensuring professional realisation and a better life, self-organising within the community under the leadership of successful and educated Roma and the fight against the predominant stereotypical mainstream narratives about the Gypsies as criminals and beggars - were all related to the vision that the Romani community as a collective should mobilise itself and take actions in the framework of the existing social structures and be part of the up-to-date social processes. These three strategic areas expressed in the newspaper fit fully into the discourse and known programmes of the existing Roma civil organisations of the interwar period in Yugoslavia and the region of South Eastern and Central Europe (Marushiakova \& Popov, in press) and, similar to them, sought for Romani community advancement. On the other hand, they were also in unison with some of the major Yugoslav social development discourses of the time, for modernisation (upgrading and profession- alisation of crafts), strategies for increasing literacy, and the educational advancement of the population, and community participation and representation through organisations set up and led by the educated elite. What is interesting to point out here is the fact that these pleas were directed towards the Roma themselves, who had to awaken and self-organise for the sake of their own community. Without underestimating the fact that the lack of critique might be explained with the general atmosphere of the Yugoslav regime of the mid 1930s (that was far from welcoming to critique of the authorities at any level), we should also stress the fact that analysing the Romano lil/Ciganske novine articles, it is clear that, according to their discourse, the social inclusion of interwar Yugoslavia was “in Roma's own hands” (Simić, 1935b, p. 1). According to the writings of Simić on the pages of Romano lil/Ciganske novine, community changes were a question of Romani's own agency, initiative and selforganisation. The writings outlined a path for achieving a better future through using the already existing mechanisms of the nation-state's social and political environment. The critique towards negative developments in the social environment was not lacking, and Romano lil/Ciganske novine also engaged in a critique towards generalising negative presentations of the Gypsies.

All three 'programme' areas for social inclusion appear to be comparable with the ideas of the Yugoslav activism of later periods, both in the time of Yugoslav Socialism and in the transition period. The emphasis on Romani education has persistently been present in the social inclusion discourse throughout all historical periods. However, the overall strategic aims and justification of the need for it have transformed and shiftedwhile the interwar period visions were focused, in the spirit of the time, on the cultural elevation and working habits, the discourse of socialist and post-socialist periods has stressed the need for primary and secondary education in order to access and be competitive in the labour market, and, in the decades after 2000, on increasing the number of Romani students enrolled in universities. On the other hand, the discourse on the need for self-organisation and the critique of the society have developed into new nuances, dimensions and phraseology. Looking at this resemblance with some of the messages of nowadays Romani activisms, one is astonished and tends to think how little has changed despite the fact that a century has passed.

\section{Acknowledgments}

I'd like to acknowledge the cooperation and collegial support of Dragoljub Acković who shared archival materials from his personal archive, including original documents of Svetozar Simićs personal archive and Romano lil/Ciganske novine's archive, and for all discussions on the Romani organisations and activism in Yugoslavia. In addition, I'd like to express my gratitude to the ERC project "Romalnterbellum: Roma Civic Emancipation be- 
tween the Two World Wars," led by Elena Marushiakova as Principal Investigator, for the opportunity to research the exciting topic of Roma activisms and journalism in interwar Yugoslavia.

\section{Conflict of Interests}

The author declares no conflict of interests.

\section{References}

Achim, V. (2004). The Roma in Romanian history. Budapest: CEU Press.

Acković, D. (2000). Samoorganizovanje beogradskih Roma u periodu između dva svetska rata [The selforganisation of Belgrade Roma in the period between the two world wars]. In M. Macura (Ed.), Cigani/Romi $u$ prošlosti $i$ danas [Gypsies/Roma in the past and today] (pp. 97-110). Belgrade: SANU, Komisija za proučavanje života i običaja Roma.

Acković, D. (2014). Pisani svetovni i duhovni tekstovi na romskom i o Romima [Written secular and sacred texts in Romani and about Roma]. Belgrade: Rrominterpress.

Banac, I. (1988). The national question in Yugoslavia. Origins, history, politics. Ithaca, NY: Cornell University Press.

Berberski, S. (1969). Uvodna reč Slobodana Berberskog [Slobodan Berberski's opening address]. In Osnivačka skupština Društva Rom Beograd [The founding assembly of the Rom Association, Belgrade] (pp. 45-52). Šabac: Štampa "Dragan Srnić."

Berberski, S. (1973). Radjanje [Birth]. Krlo e Rromengo, 1, 4-5.

Dimić, L. (1996). Kulturna politika u Kraljevini Jugoslaviji 1918-1941 [Cultural policy of the Kingdom of Yugoslavia, 1918-1941]. Belgrade: Stubovi kulture.

Đurić, R. (1987). Seobe Roma: krugovi pakla i venac sreće [Roma migrations: Circles of hell and a wreath of happiness]. Belgrade: Beogradski izdavačko-grafički zavod.

Đurić, R. (2009, April 28). Društvo predrasuda [A society of prejudices]. Politika. Retrieved from http://www. politika.rs/scc/clanak/84881

Gheorghe, N. (2013). Choices to be made and prices to be paid: Potential roles and consequences in Roma activism and policy-making. In W. Guy (Ed.), From victimhood to citizenship: The path of Roma integration (pp. 41-100). Budapest: Kossuth Kiadó/Central European University Press.

Gligorijević, B. (1986). Jugoslovenstvo izmedju dva rata [The Yugoslavianhood between the two wars]. Jugoslovenski istorijski časopis, 21, 71-97.

Jašić, N. (2001). Stari niški Romi [Old-time Roma of Niš]. Niš: KSS.

Jopson, N. B. (1936). Romano lil (Tsiganske novine). Journal of the Gypsy Lore Society, 15(2), 86-91.

Marushiakova, E., \& Popov, V. (2005). The Roma: A na- tion without a state? Historical background and contemporary tendencies. In W. Burszta, T. Kamusella, \& S. Wojciechowski (Eds.), Nationalisms across the globe: An overview of the nationalism of stateendowed and stateless nations (pp. 433-455). Poznan: School of Humanities and Journalism.

Marushiakova, E., \& Popov, V. (2016). Roma culture and Roma policies. In E. Marushiakova \& V. Popov (Eds.), Roma culture: Myths and realities (pp. 237-242). Munich: Lincom Academic Publishers.

Marushiakova, E., \& Popov, V. (Eds.). (in press). Roma voices in history: A source book. Leiden: Brill Publishers.

Milić, M. (1935). Naša „inteligencija” i „aristokratija” [Out "intelligentsia" and "aristocracy"]. Romano lil/Ciganske novine, 3, 2.

Mitrović, D. (1936). Podnevne slike prvog ciganskog novinara kod nas u Karađorđevom parku [Midday pictures of our first Gypsy journalist]. Vreme.

Nikolić, D. (1939). Neobičan događaj u obojenom narodu. Beogradski ciganski klub pred velikim zadatkom....Može li ot Cigana nešto da bude? [An unusual event among the dark-skinned people. The Belgrade Gypsy Club facing a big task....Could the Gypsies achieve anything?]. Politika, 4, 10.

Petrović, A., \& Simić, S. (1934a). O braku kod naših Cigana [About the marriage among our Gypsies]. Belgrade: Authors.

Petrović, A., \& Simić, S. (1934b). O veri naših Cigana [About the belief among our Gypsies]. Belgrade: Authors.

Petrović, A., \& Simić, S. (1934c). Kradja kod Cigana [Theft among Gypsies]. Belgrade: Authors.

Petrović, A. (1935, May 12). Letter to Scott Macfie (GLS A1-35, GLS I-XLIII). The Gypsy Lore Society Archive, University of Liverpool, UK.

Petrović, A. (1937). Contributions to the study of the Serbian Gypsies: No. 10. Journal of the Gypsy Lore Society, 16 (3), 111-137.

Roma Education Fund. (2010a). Strategy 2010-2015. Budapest: Roma Education Fund.

Roma Education Fund. (2010b). Advancing education of Roma in Serbia. Country assessment and the Roma Education Fund's strategic directions. Budapest: Roma Education Fund.

Simić, S. (1935a). Naša prva reč [Our first word]. Romano lil/Ciganske novine, 1, 1.

Simić, S. (1935b). Romano lil [Romani newspaper]. Romano lil/Ciganske novine, $3,1$.

Swedish town becomes first in country to introduce licence fees for beggars. (2019, August 2). The Local. Retrieved from https://www.thelocal.se/20190802/ swedish-town-introduces-paid-permits-for-beggars

Uhlik, R. (1937). Romane gjilja. Ciganske pesme [Romani songs. Gypsy songs]. Prijedor: Štamparija Vučen Štrbac.

Uhlik, R. (1938). O devlikano ramope e Sumnale Lukahtar nakhadino pe romani chib katar Rade Uhlik sikamno 
[The holy text of the Gospel of Luke translated into Romani language by Rade Uhlik researcher]. Belgrade: Englezongo thaj avere themengo Biblijako amalipe.

Vukanović, T. (1983). Romi (Cigani) u Jugoslaviji [Roma
(Gypsies) in Yugoslavia]. Vranje: Nova Jugoslavija. Žutić, N. (1991). Sokoli. Ideologija u fizičkoj kulturi Kraljevine Jugoslavije 1929-1941 [Falcons. Ideology of the physical culture in the Kingdom of Yugoslavia 1929-1941]. Belgrade: Angrotrade.

\section{About the Author}

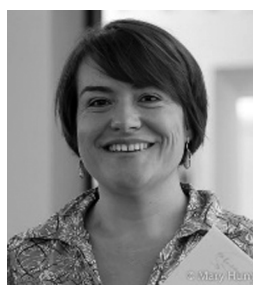

Sofiya Zahova is a Research Fellow at the School of History, University of St Andrews, and Researcher at the University of Iceland. Her main interests are in the field of Romani Studies, History and Ethnography of the Balkans and Eastern Europe. She is author of the books Montenegro after Yugoslavia: Dynamics of Identities (2013, in Bulgarian), History of Romani Literature with Multimedia on Romani Kids' Publications (2014) and co-editor of the volume Ethnography of Migrations. The Bulgarians in the Mediterranean (2013). 